\title{
Air Pollution, Road Proximity, Greenspace, Indoor Air Pollution and Reduced Lung Function Incidence in Children : A Case-control Study
}

\section{Jingwei Zhang}

Department of Environment and Health, Tianjin Centers for Disease Control and Prevention

\section{Yuming Wang}

School of Public Health, Tianjin Medical University

\section{Lihong Feng}

Department of Environment and Health, Tianjin Centers for Disease Control and Prevention

\section{Changchun Hou}

Department of Environment and Health, Tianjin Centers for Disease Control and Prevention

Qing Gu ( $\sim$ guqing1014@163.com )

Tianjin Centers for Disease Control and Prevention https://orcid.org/0000-0001-6471-1272

\section{Research Article}

Keywords: Air pollution, Road proximity, Greenspace, Indoor air pollution, Reduced lung function

Posted Date: July 7th, 2021

DOl: https://doi.org/10.21203/rs.3.rs-633168/v1

License: (c) (1) This work is licensed under a Creative Commons Attribution 4.0 International License.

Read Full License 


\section{Title Page}

2 Air pollution, road proximity, greenspace, indoor air pollution and reduced lung function incidence in children: A Case-control Study

$6 \quad{ }^{a}$ Department of Environment and Health, Tianjin Centers for Disease Control and Prevention, No.6 Huayue Rd. Tianjin, China

$7 \quad$ b School of Public Health, Tianjin Medical University, No.22 Qixiangtai Rd. Tianjin, China

\section{Abstract}

Objectives: Reduced lung function during childhood could substantially influence the health states of the respiratory system in adults, so, the relationships between air pollution, road proximity, greenspace, indoor air pollution and reduced lung function incidence in children were investigated in this study.

Methods: The lung function of children was tested every year from 2015 to 2018 and the method of case-control study was applied. Propensity score matching (PSM) was performed to minimize confounding bias and the conditional logistic regression model was carried out to evaluate the effects of indoor and outdoor environmental risk factors on reduced lung function of children.

Results: Each-one quartile increment in the mixture of the six air pollutants at lag1, lag 2 and lag 3 periods were related to $46.2 \%, 9.57 \%$ and $8.28 \%$ increased risk levels of getting the unhealthy outcome. The protective effect of greenness at lag2 period (Odds ratios $(\mathrm{OR})=0.01(95 \%$ confidence interval $(\mathrm{CI})$ : 0 - 0.02$)$ ) was stronger than that at lag1 period (OR $=0.03(95 \%$ CI: $0.01-0.05)$ ).

Conclusions: Separate and combined effects of most air pollutants at different lag periods represented the hazard effects to the lung function of students. And the distance band of 101-200 m between the home address of each student and the major road could be detrimental to the health of the lung of children significantly. Exposure levels of greenness had protective effects on lung health for students. Only the indoor factor of secondhand smoke exposure was significantly associated with an elevated risk of having reduced lung function.

Key words: Air pollution; Road proximity; Greenspace; Indoor air pollution; Reduced lung function 


\section{Air pollution, road proximity, greenspace, indoor air pollution and reduced lung function incidence in children: A Case-control Study}

\section{Introduction}

Because of the imperfect immune system and immature physiological functions, children are more sensitive to the damage of pollutants in the external environment. There are great differences in the physiological characteristics of the lung between children and adults. The inspiratory capacity of children is larger than that of adults, so more environmental pollutants could be inhaled(Collaborators \& Renzaho, 2019). And the ventilation rate of children is higher than that of adults, which could increase the frequency of direct contact of environmental pollutants with the respiratory tract(Laborde et al., 2015). Moreover, the airway epithelium of children is more permeable to environmental pollutants, so that pollutants are more likely to cause direct damage to children's tissues and organs, especially the lung(Miller et al., 2016). Based on the above characteristics, environmental pollutants are further inclined to endanger children's lung function through the respiratory tract of children.

In recent years, because of the growth of China's economy, the problems related to air pollution have become more serious(Yu et al., 2019). A study has shown that air pollutants can directly cause the imbalance of microflora in the lungs, and then damage the lungs, leading to the occurrence of disease(Yu et al., 2016). At the same time, $\mathrm{PM} 2.5$ can increase the expression of interleukin-17a (IL-17a) in lung and concentrations of lymphocytes in peripheral blood, and then result in inflammatory effects of the lung(Chao et al., 2020). Air pollutants can also cause damage to lung function in children. A cohort study showed that if concentrations of $\mathrm{PM}_{10}$ and $\mathrm{NO}_{2}$ in the air decreased by 14.1 ppb and $8.1 \mu \mathrm{g} / \mathrm{m}^{3}$, forced expiratory volume in one second (FEV1\%) in children increased by $91.4 \mathrm{ml}$ and $65.5 \mathrm{ml}$, respectively(Gauderman et al., 2015). A cross-sectional study conducted in Uganda showed that the lung function of children in heavily polluted areas was lower than that in regions with lighter air pollution (Kirenga et al., 2018).

In recent years, as the number of motor vehicles increases, it has caused serious air pollution caused by traffic(Mou et al., 2018). In urban areas, nitrogen oxides (NOx) are 

years was decreased by $15.8 \mathrm{ml}$ (Schultz et al., 2016). The Child Heart and Health Study in England (CHASE) found that all traffic-related air pollutants except ozone (O 3 ) would adversely affect indicators of lung function (such as FEV1 and forced vital capacity (FVC)) in children (Barone-Adesi et al., 2015). Traffic pollutants can also lead to respiratory diseases in children and some researchers regarded the distances between the home addresses and the road as the severity of traffic-related air pollutants. An investigation carried out in Korea discovered living close to the main road ( $<75 \mathrm{~m}$ ) could increase the risk of having asthma by 3.62 times in children (Lee et al., 2018 ). When the distance between the home address and the freeway was smaller than 500m, a remarkable reduction in FEV1 of children who lived there was found in California(Urman et al., 2014).

Recently, increasing numbers of researches focused on the effects of greening levels of residential environments on child health. For children, more greenness exposures correlated with reductions in sedentary behaviors and the obesity rate(Paciência \& Moreira, 2017). The natural environment around the residency site could favor the regulation of immune reactions mediated by TH1and TH2 cells(Ruokolainen et al., 2015). A birth cohort study found that, within the 100 and $200 \mathrm{~m}$ buffer scales, more greenness exposures near the location of residence could be beneficial for the increase in FEV1 and FVC of children, respectively(Fuertes et al., 2020). The Respiratory Health in Northern Europe, Spain and Australia (RHINESSA) study showed that the lower levels of greenness exposure in childhood, adolescence and adulthood were more unlikely related to increased risks of asthma and rhinitis onsets, but could lower pulmonary function in adulthood(Nordeide Kuiper et al., 2021). Nevertheless, a European cohort study indicated that green space exposures during the antenatal and postnatal periods were not associated with the change of FEV1 of children aged 6-12 years(Agier et al., 2019).

Based on the report by World Health Organization (WHO), almost 4.3 million premature deaths and 110 million disability-adjusted life years lost annually were attributed to household air pollution (HAP)(Raju et al., 2020). In China, HAP originates from indoor cooking and heating, especially in rural regions(Deng et al., 2020). Carbon monoxide (CO) was regarded as one kind of HAP generated from the cooking process, and prenatal CO exposure could be detrimental to the development of lung function of offsprings (Lee et al., 2019). In the meantime, adolescents exposed to secondhand smoke were more susceptible to have reduced lung function and wheeze(Pulvers et al., 2020). Besides, a cohort study considered heating, cooking and smoking as HAPs, and found that these factors were all negatively correlated with health states of lung function of adults(Dai et al., 2021). Since children spent a substantial amount of time indoors, HAPs should be treated as essential factors when considering the potential health hazard of them to the respiratory systems of children.

Although numerous studies have investigated relationships between lung function of children and air pollution, road proximity, greenspace and indoor air pollution, respectively, most of the studies were accomplished in developed countries and conclusions were inconsistent. Reduced lung function during childhood could substantially influence the health states of the respiratory system in adults(Oerlemans et al., 2020). Because of geographical differences, the toxic effects of pollutants could be varied. Moreover, few studies analyzed environmental pollutants outside (such as pollution, road proximity, greenspace) and inside (indoor air pollution), and remove effects of the confounding bias simultaneously. Therefore, this study investigated the relationship between air pollution, road proximity, greenspace, indoor air pollution and reduced lung function incidence 

elements, which exerted deleterious effects on the lung function of children, could be identified and the results may provide evidence for policy development of promoting children's health.

\section{Methods}

\section{Study area}

Tianjin, one of four municipalities directly under the central government, is the largest industrial and commercial port city in northern China. The climate is under the influence of the warm temperate semi-humid monsoon. In recent years, the plan of promoting urban greening was valued as a key project, and there are 11 main kinds of plant species in Tianjin. At the same time, due to the advanced transportation, the socioeconomic of Tianjin was very well developed. By the end of 2018 , the total mileage of highways has been $4243 \mathrm{~km}$. In this study, Heping, Hexi, Nankai and Hongqiao District were selected as representative of the urban area, Dongli and Beichen District were chosen as representative of the sub-urban area, Baodi District was chosen as representative of the rural area. There were 7 districts in total included in this study. (Fig. S1)

\section{Study Design and Participants}

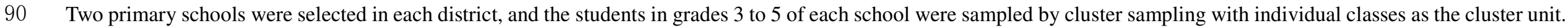
150 samples were randomly selected each time for one district. Based on the lifestyles of residents and climatic characteristics in Tianjin, pulmonary function tests were performed on students during the heating season (from November 15 to December 31) each year from 2015 to 2018 . According to the previous study, when the pulmonary function index (FEV1/FVC) of the child was less than or equal to 0.7, this student was diagnosed with reduced lung function(Geyti et al., 2020). Due to the low incidence of reduced lung function in children, this study persisted for three years to obtain enough cases. In total, 3150 students were experienced by the lung function test. To avoid the interference effects of the history of some respiratory diseases, students who were suffering from any health conditions, such as having a thoracic surgery history, or having a history of asthma were excluded from this study. On account of the missing information such as the home address, height and weight, some students were also excluded. Ultimately, 2087 students were included in this study, in which there were 106 cases diagnosed with reduced lung function and 1981 healthy controls. Therefore, the method of case-control study was used to inspect the risk factors of reduced lung function in children.

\section{Lung Function Measurements}

In this study, the lung function of each student was measured by the 6880 electronic air spirometer (6880, Vitalograph Ltd., UK). The measured lung function indicators included FVC, peak expiratory flow (PEF), FEV1, 75\% forced expiratory volume (FEF75) and 25\% forced expiratory volume (FEF25). Due to the circadian rhythms in human biological indicators, every child was tested at the same time interval on the test day (8:00-12:00), and the measurement methods referred to the 2005 ATS/ERS recommendations(Miller et al., 2005). Exercise, drink water or eat before the test were prohibited. In order to ensure the accuracy of the results, the lung function of each student was tested 2 to 5 times. When the relative difference between the two results was less than $10 \%$, the higher was employed in the next step analysis. 


\section{Air Pollution Exposure}

There were 27 environmental monitoring sites in Tianjin, which routinely monitored the daily concentrations of major atmospheric pollutants such as fine particulate matter $\left(\leq 2.5 \mu \mathrm{m}\right.$ in aerodynamic diameter; $\left.\mathrm{PM}_{2.5}\right)$, inhalable particulate matter $\left(\mathrm{PM}_{10}\right)$, nitrogen dioxide $\left(\mathrm{NO}_{2}\right)$, Sulphur dioxide $\left(\mathrm{SO}_{2}\right)$ and the daily maximum of 8 hours means for ozone $\left(\mathrm{O}_{3}-8 \mathrm{~h}\right)$. At the same time, this study collected the resident address of each student, and concentrations of major atmospheric pollutants obtained from each monitoring station. Land use, meteorological and satellite data were also collected to fit the land use regression (LUR) model to estimate the air pollution exposure levels around the home address of each student during the study period. The details of the LUR model were described in the previous research, and $78 \%, 73 \%$ and $76 \%$ of the variabilities in daily concentrations of $\mathrm{PM}_{2.5}$ in monitor sites could be explained by the LUR model in 2015, 2016 and 2018, respectively(Zhang et al., 2020). The estimated concentrations of air pollutants around the residential address represented air pollution exposure levels of students, and the exposure levels of the one quarter (lag1), two quarters (lag2) and three quarters (lag3) before the day of testing lung function were assessed. If a student moved during the study period, the exposure levels would be evaluated by the residence time in each address.

\section{Greenness}

Normalized Difference Vegetation Index (NDVI) was used as a representative of greenness in this study. The range of NDVI is from -1 to 1. When the NDVI is negative, that means the ground is covered by cloud, water, snow and other materials, however, when the index is positive, it indicates that the ground is covered by vegetation and the index increases with the increasing extent of land surface vegetation cover. Because of the climate characteristics in Tianjin, the situation of vegetation cover in the hot season was different from that in the cold season. Two-time windows, which included one quarter (lag1) and two quarters (lag2) before the day of testing lung function, were considered in this study. The relevant data from 2015 to 2018 was downloaded from the Landsat Enhanced Thematic Mapper Plus (ETM+) (https://earthexplorer.usgs.gov/). According to the previous study, the buffer was defined as an area with a radius of 100 meters around the residential address, and the average NDVI value represented the exposure level of the greenness of each student(Yuchi et al., 2020).

\section{Road proximity}

Distances between the home address and the road could be regarded as the severity of traffic-related air pollutants. In this study, the distance between home address of each student and the major road was calculated by using ArcGIS (ArcGIS version 10.3, ESRI). The major road was defined as the road with 4 bi-direction lanes, and the distances between the residential addresses and the major road were classified into 6 kinds of distance bands: 0-50 m, 51-100 m, 101-200 m, 201-300 m, 301-400 m and >400 m.

\section{Indoor air pollution and Covariates}

According to the previous researches and life habits of local people in Tianjin, the situations of indoor air pollution, which included secondhand smoke exposure, fuel used for cooking, the method of heating and the air purifiers utilization, were obtained by the questionnaire. The above factors were defined as dichotomic variables. Using only electricity, natural gas and biogas for cooking were classified as consuming clean fuels. Otherwise, using other kinds of fuels was classified as consuming non-clean fuels. 
Either having central heating or using electricity for heating was defined as using clean energy. But utilizing coal or wood for heating was defined as using non-clean energy. Meanwhile, students were asked whether experiencing secondhand smoke at home during the past week and whether using air purifiers in polluted weather in Tianjin. In the meantime, sex, height, weight, educational attainment levels of parents of each student were collected and regarded as covariates in this study.

\section{Statistical Analysis}

In this study, air pollution, road proximity and greenspace were considered as environmental risk factors outdoors, and secondhand smoke exposure, fuel used for cooking, the method of heating and the air purifiers utilization were regarded as indoor air pollution factors. Indoor air pollution factors were used to perform propensity score matching (PSM) for students to estimate effects of outdoor environmental risk factors on reduced lung function in children (Eq. 1-3), and outdoor environmental risk factors were used to perform PSM to investigate effects of indoor air pollution factors (Eq. 4). The matching weight of 1:1 was applied to moderate the effects of confounders. Because the PSM was used in this study, the conditional logistic regression model was carried out to evaluate the effects of indoor and outdoor environmental risk factors on reduced lung function of children. Since there were strong correlations between exposure levels of outdoor air pollutants and traffic pollution, concentrations of air pollutants and exposure levels of traffic pollution could be not included in the model at the same time(Zhu et al., 2017).

$$
\log \left(\frac{\pi_{j}}{1-\pi_{j}}\right)=\beta_{t} A P_{t}+\text { Greenness }_{t}+\text { Sex }+B M I+\text { Parental education level }+ \text { strata }(I D)
$$

$$
+ \text { indoor } \text { factors }_{i}
$$

$$
\log \left(\frac{\pi_{j}}{1-\pi_{j}}\right)=\beta \text { Road proximity }+ \text { Greenness }_{t}+\text { Sex }+ \text { BMI }+ \text { Parental education level }+ \text { strata }(I D)
$$

$$
+ \text { indoor factors }_{i}
$$

$$
\log \left(\frac{\pi_{j}}{1-\pi_{j}}\right)=\beta_{i} \text { indoor } \text { factors }_{i}+\text { Sex }+ \text { BMI }+ \text { Parental education level }+ \text { strata }(I D)+\text { AP }_{t}+\text { Greenness }_{t}
$$


Where $\pi_{j}$ was the probability of occurrence of having reduced lung function. AP $P_{t}$ and Greenness $s_{t}$ were the exposure levels of air pollutants and greenness during different periods. Road proximity was the distance between the home address of each student and the major road. Sex,BMI and Parental education level were the sex, body mass index (BMI) and educational attainment levels of parents of each student. indoor factors were the states of the secondhand smoke exposure, fuel used for cooking, the method of heating and the air purifiers utilization of each student. ID was sequence accession numbers of matched sets after PSM.

Since correlations of air pollutants were statistically significant sometimes, and multiple air pollutants were included in the model simultaneously could lead to the over- or under-estimation of the effect of a single air pollutant on the health outcome. Consequently, Quantile g (qg) -computation was applied in this study to investigate the joint effects of the mixture of air pollutants on the reduced lung function incidence in children. Qg -computation was a novel parametric statistical method, and the percent change (95\%CI) of having reduced lung function for each one quantile of all air pollutants exposures in the mixture increase was estimated in this study.

\section{Sensitivity Analysis}

For sensitivity analysis, effects of indoor and outdoor environmental risk factors on reduced lung function of children were evaluated in different sex (male vs female) and BMI (overweight vs non-overweight) subgroups. Referring to the industry standard WS/T 586-2018, students were identified as overweight or not. In addition, the exposure of greenness in $500 \mathrm{~m}$ and $1000 \mathrm{~m}$ buffers around the home address were also considered in this study. All statistical analysis was conducted with $\mathrm{R}$ software, version 4.0 .2 ( $\mathrm{R}$ Foundation for Statistical Computing, Vienna, Austria). The study was approved by the Committee on the Ethics of Tianjin Centers for Disease Control and Prevention (permit number: TJCDC0111).

\section{Results}

\section{Descriptive Statistics}

In total, 1981 cases and 106 controls were included in this case-control study. Before PSM, there was no significant difference in some personal characteristics such as BMI and sex ratio. For the environmental factors outside, exposure levels of air pollutant concentrations, greenness and the proportion of the distance band of $201-300 \mathrm{~m}$ in the road proximity in the students diagnosed with reduced lung function were higher than those in healthy students. For instance, concentrations of PM ${ }_{2.5}$ exposure during lag1 and lag3 period were higher in the students diagnosed with reduced lung function. For the indoor air pollution factors, significant differences were recorded in secondhand smoke exposure and the method of heating between cases and controls. (Table 1)

Indoor air pollution factors were used to perform PSM to estimate effects of outdoor environmental risk factors on reduced lung function in children. No significant differences between cases and controls in indoor air pollution factors were showed and significant differences were found among almost all the environmental risk factors outside between cases and controls. For example, the medians (interquartile range (IQR)) of NDVI, $\mathrm{PM}_{2.5} \operatorname{lag} 1$ and PM 10 lag1 in healthy children were 0.52 (0.14), 36.23 (11.65) and 48.78 (29.95), which were larger than those in students diagnosed with reduced lung function, respectively. Meanwhile, the proportion of the distance band of 201-300 $\mathrm{m}$ in the road proximity in the students diagnosed with reduced lung function was $36.8 \%$, which was higher than that in healthy students (16\%). (Table 1 ) 
After PSM based on the outdoor environmental risk factors, the percentage of secondhand smoke exposure in the students diagnosed with reduced lung function was $30.2 \%$, which was higher than that in healthy students (16\%). (Table 1)

\section{Health effects of outdoor environmental risk factors after PSM}

Most of the correlations among air pollutants in different periods were statistically significant. Except for $\mathrm{O}_{3}-8 \mathrm{~h}$, the remaining air pollutants significantly positively correlated with each other. The correlation between $\mathrm{PM}_{2.5} \mathrm{lag} 1$ and $\mathrm{PM}_{2.5}$ lag2 was the strongest $(\mathrm{r}=0.983)$. At the same time, there was no significant association between NDVI and air pollutants, except for $\mathrm{NO}_{2}$, which had a negative correlation with NDVI. In addition to $\mathrm{O}_{3}-8 \mathrm{~h}$, distances between the home address of each student and the major road correlated inversely with concentrations of air pollutants (Table S1) (Fig. S2). According to the relationships of outdoor environmental risk factors above, the conditional logistic regression model was applied to evaluate the effects of outdoor environmental risk factors.

\section{Air pollutant}

When a single air pollutant was included in the model, and sex, height, weight, indoor air pollution exposure and educational attainment levels of parents of each student were considered as covariates, it was found that, apart from $\mathrm{O}_{3}-8 \mathrm{~h}$, most air pollutants were harmful to the lung function of students. The results from the conditional logistic regression model were obtained in the form of odds ratios (ORs), which were presented graphically as forest plots. (Fig.1) For example, the OR of 1.02 (95\% confidence interval (CI): 1.01 - 1.04), OR of 1.03 (95\% CI: 1.02 - 1.04), and OR of 1.05 (95\% CI: 1.02 - 1.07) suggest that children diagnosed with reduced lung function tended to have higher exposure levels of $\mathrm{PM}_{10} \mathrm{lag} 1, \mathrm{PM}_{2.5}$ lag2 and $\mathrm{SO}_{2} \mathrm{lag} 3$, respectively. For $\mathrm{PM}_{2.5}$ and $\mathrm{SO}_{2}$, exposure at one quarter before the day of testing lung function (lag1) exerted the strongest damaging effects, with the OR of 1.04 (95\% CI: 1.02 - 1.06) and OR of 1.4 (95\% CI: 1.11 - 1.76) for PM $\mathrm{P}_{2.5}$ and $\mathrm{SO}_{2}$, respectively. For particulate pollutants, An increase of $10 \mu \mathrm{g} / \mathrm{m}^{3}$ in concentrations of $\mathrm{PM}_{2.5}$ was associated with $3.9 \%, 2.9 \%$ and $3.3 \%$ increases in the risks of having reduced lung function at the lag $1(\mathrm{OR}=1.039(95 \%$ CI : 1.02 - 1.06)), lag $2(\mathrm{OR}=1.03(95 \% \mathrm{CI}: 1.02-1.04))$ and lag $3(\mathrm{OR}=1.033(95 \% \mathrm{CI}: 1.02-1.05))$ period, and the damaging effects of PM 2.5 at different lag periods were stronger than those of $\mathrm{PM}_{10}$ at the lag $1(\mathrm{OR}=1.022(95 \% \mathrm{CI}: 1.01-1.04))$, lag $2(\mathrm{OR}=1.028(95 \% \mathrm{CI}: 1.01-1.05))$ and lag $3(\mathrm{OR}=1.023(95 \% \mathrm{CI}: 1-1.04))$ period, respectively. Moreover, the strongest injurious effect was seen at $\mathrm{SO}_{2}$ exposure at the lag1 period (OR $=1.399$ (95\% CI: $\left.1.11-1.76\right)$ ). However, the OR of 0.99 (95\% CI: 0.98 - 1), OR of 0.983 (95\% CI: 0.97 - 0.99), and OR of 0.978 (95\% CI: 0.97 - 0.99) suggest that children diagnosed with reduced lung function tended to have lower exposure levels of $\mathrm{O}_{3} \operatorname{lag} 1, \mathrm{O}_{3} \mathrm{lag} 2$ and $\mathrm{O}_{3} \mathrm{lag} 3$, respectively. Besides, when both NDVI and a single air pollutant were included in the model simultaneously, the degree and direction of effects of air pollutants were not changed significantly. (Fig.1).

Through Quantile g (qg) -computation, the joint effects of the mixture of air pollutants on the reduced lung function incidence in children were estimated. Each one quartile increment in the mixture of the six air pollutants at lag1, lag2 and lag 3 time periods was related to $46.2 \%, 9.57 \%$ and $8.28 \%$ increased risk levels of getting the unhealthy outcome. Joint effects at one quarter before the testing day were strongest. (Fig.2) (Table 2)

Subgroup analyses were carried out according to the different sex and BMI statuses. With the exception of $\mathrm{O}_{3}-8 \mathrm{~h}$, the harmful effects of nearly all air pollutants were stronger 
in females than males. For example, the damaging effects of $\mathrm{PM}_{2.5}$ in females at the lag $1(\mathrm{OR}=1.08(95 \% \mathrm{CI}: 1.02-1.14))$, lag $2(\mathrm{OR}=1.05(95 \% \mathrm{CI}: 1.03-1.08))$ and lag $3(\mathrm{OR}=1.05(95 \% \mathrm{CI}: 1.02-1.08))$ periods were stronger than those of $\mathrm{PM}_{2.5}$ in males at the lag $1(\mathrm{OR}=1.03(95 \% \mathrm{CI}: 1.01-1.05))$, lag $2(\mathrm{OR}=1.02(95 \% \mathrm{CI}: 1.01-$ $1.03))$ and lag $3(\mathrm{OR}=1.02(95 \% \mathrm{CI}: 1.01-1.04))$ periods. Furthermore, the strongest harmful effect was also presented at $\mathrm{SO}_{2}$ at the lag1 period $(\mathrm{OR}=1.34(95 \% \mathrm{CI}: 1.06$ - 1.71) in female. (Fig. S3) For the grouping variable of BMI, when a single air pollutant was included in the model, dangerous effects of $\mathrm{PM}_{2.5}$ and $\mathrm{SO}_{2}$ at all three lag periods were stronger in overweight students than those of $\mathrm{PM}_{2.5}$ and $\mathrm{SO}_{2}$ in the non-overweight. For instance, the damaging effects of $\mathrm{SO}_{2}$ in the overweight at the lag $1(\mathrm{OR}=1.29$ $(95 \% \mathrm{CI}: 1.05-1.59))$, lag $2(\mathrm{OR}=1.07(95 \% \mathrm{CI}: 1.03-1.11))$ and lag $3(\mathrm{OR}=1.05(95 \% \mathrm{CI}: 1.02-1.08))$ periods were stronger than those of $\mathrm{SO}_{2}$ in the non-overweight at the lag $1(\mathrm{OR}=1.18(95 \% \mathrm{CI}: 1.06-1.32))$, lag $2(\mathrm{OR}=1.05(95 \% \mathrm{CI}: 1.03-1.07))$ and lag $3(\mathrm{OR}=1.04(95 \% \mathrm{CI}: 1.02-1.06))$ periods, respectively. (Fig. S4)

\section{Road proximity}

Based on the distances between the residential address and the major road, the road proximity was classified into 6 kinds of distance bands and the distance band of more than $400 \mathrm{~m}$ was used as the reference control. It was found that only the distance band of 101-200 $\mathrm{m}$ could be detrimental to the lung function of children significantly (OR $=4.67$ (95\% CI: $1.21-8.13)$ ), but effects of other distance bands on the health of the lung were established to be statistically insignificant. (Fig.3) Furthermore, when the greenness was considered as the covariate in the model, impacts of the road proximity were all not changed significantly. (Fig.3)

\section{Greenness}

Exposure levels of greenness at one quarter and two quarters before the day of testing lung function of each student had a protective effect on lung health, and the effect of lag2 period $(\mathrm{OR}=0.01(95 \% \mathrm{CI}: 0-0.02)$ ) was stronger than that of lag1 period ( $\mathrm{OR}=0.03(95 \%$ CI: $0.01-0.05))$. (Fig.4) Greenness in $500 \mathrm{~m}$ and $1000 \mathrm{~m}$ buffers around the home address were also considered in this study and results did not show larger variation (data not shown).

Subgroup analyses for the BMI and sex were performed. For the period of one quarter (lag1) before the day of testing lung function, protective effects of greenness in the female and overweight subgroup were stronger than those in other subgroups, respectively. For example, the OR of 0.017 (95\% CI: 0 - 0.03) in the overweight was smaller than the OR of 0.023 (95\% CI: 0 - 0.04) in the non-overweight. But for the lag2 period, protective effects of greenness were stronger in the non-overweight subgroup. (Fig. S5-6) (Table S2-3)

\section{Health effects of indoor air pollution risk factors after PSM}

When a single indoor air pollution risk factor was included in the model, and the exposure levels of outdoor environmental risk factors, sex, height, weight, educational attainment levels of parents of each student were considered as covariates, it was found that only the factor of secondhand smoke exposure was significantly associated with the elevated risk of having reduced lung function $(\mathrm{OR}=2.4(95 \% \mathrm{CI}: 1.2-3.6))$. Furthermore, after adjusted by other indoor air pollution factors, and the result showed that the effect of secondhand smoke exposure was slightly elevated ( $\mathrm{OR}=2.98$ (95\% CI: 1.39 - 4.56)). (Fig. 5) (Table 3)

Subgroup analysis was performed for exploring the differences of effects of secondhand smoke exposure on the adverse health outcome between the two subgroups, but 
nonsignificant associations were found in each subgroup. (Fig. S7) (Table S4)

\section{Discussion}

In this study, for the outdoor air pollution factors, it was found that, apart from O3-8h, the separate and combined effects of most air pollutants at different lag periods represented the hazard effects to the lung function of students. And the distance band of 101-200 m between the home address of each student and the major road could be detrimental to the health of the lung of children significantly. Nevertheless, exposure levels of greenness at various lag phases had protective effects on lung health for students and could not affect the associations between air pollution or road proximity and the reduced lung function incidence in children. For the indoor air pollution factors, only the factor of secondhand smoke exposure was significantly associated with the elevated risk of having reduced lung function.

This analysis was the first large population-based case-control study to investigate environmental pollutants outside and inside simultaneously and remove effects of confounding bias through the method of PSM. In this study, for $\mathrm{PM}_{2.5}$ and $\mathrm{SO}_{2}$, exposure at one quarter before the day of testing lung function (lag1) exerted the strongest damaging effects, with the OR of 1.04 (95\% CI: 1.02 - 1.06) and OR of 1.4 (95\% CI: 1.11 - 1.76) of $\mathrm{PM}_{2.5}$ and $\mathrm{SO}_{2}$, respectively. This indicated that short-term effects of these two pollutants could be strongest for lung function of students. Lung function is measured by changes in lung volume and is often used as an indicator of the impact of shortterm $\mathrm{PM}_{2.5}$ exposure on the lungs. At the same time, $\mathrm{PM}_{2.5}$ could pervade into the lungs and activate an inflammatory response to cause a decrease in lung function in a shorter time (Dauchet et al., 2018). A panel study conducted in Nanjing found that, for every $10 \mu \mathrm{g} / \mathrm{m}^{3}$ increases in the 1-day moving average $\mathrm{PM}_{2.5}$ concentration, the FVC of children was reduced by $23.22 \mathrm{~mL}$ (95\% CI: 13.19, 33.25) (Xu et al., 2018). However, one study which compared the short-term effects with the long-term effects of PM 2.5 on the lung function suggested that long-term $\mathrm{PM}_{2.5}$ exposure could exert more significant damaging effects on the FEV1 and FVC (Strassmann et al., 2021). But that study was carried out in Switzerland and the sample population was adult, and the difference in susceptible population and geography could contribute to the inconsistency (Luo et al., 2017).

In this study, for particulate pollutants, the damage effects of $\mathrm{PM}_{2.5}$ on the lung function of students were stronger than those of $\mathrm{PM}_{10}$ at different lag times, respectively. An increase of $10 \mu \mathrm{g} / \mathrm{m}^{3}$ in concentrations of $\mathrm{PM}_{2.5}$ was associated with 3.9\%, 2.9\% and 3.3\% increases in the risks of having reduced lung function at the lag $1(\mathrm{OR}=1.039$ (95\% $\mathrm{CI}: 1.02-1.06))$, $\operatorname{lag} 2(\mathrm{OR}=1.03(95 \% \mathrm{CI}: 1.02-1.04))$ and $\operatorname{lag} 3(\mathrm{OR}=1.033(95 \% \mathrm{CI}: 1.02-1.05))$ period, which were larger than the harmful effects of $\mathrm{PM} \mathrm{M}_{10}$ at the corresponding lag times. $\mathrm{PM}_{2.5}$ and $\mathrm{PM}_{10}$ are considered as particulate pollutants in the air, which can cause a series of adverse reactions such as inflammation, oxidative damage and DNA damage(Liu et al., 2020). Particulate pollutants contain heavy metals, PAHs (Polycyclic Aromatic Hydrocarbons) and water-soluble ions parts, which may influence pulmonary function of children(Zhang et al., 2020). However, compared with $\mathrm{PM}_{10}, \mathrm{PM}_{2.5}$ has smaller diameter, which can penetrate the respiratory tract easily, thus causing greater harm to human health(Wu et al., 2020). A cross-sectional multicenter study conducted in China found that, the damaging effects of $\mathrm{PM}_{2.5}$ on having lung function impairment in children were larger than those of $\mathrm{PM}_{10}$. For every 1 quartile increase in daily average concentrations of $\mathrm{PM}_{2.5}$ and $\mathrm{PM}_{10}$, the incidence of lung function impairment increased by 1.27 (95\% CI: 0.79-1.88) and 0.93 (95\% CI: 0.58-1.37), respectively. Since the predicted spirometric values for children in northeast China were used as the reference to define the reduced lung function in this study, the effects of this multicenter study were stronger than ours(Zhang et al., 2019). 
$\mathrm{O}_{3}$ is a strong oxidant and free radicals could be produced by the reactions between $\mathrm{O}_{3}$ and epithelial lining fluid. The concentrations of inflammatory factors such as interleukin (IL) -6 , IL- 8 and tumor necrosis factor $\alpha(\mathrm{TNF} \alpha)$ was increased in bronchial epithelial cells exposed to $\mathrm{O}_{3}$ in vitro and $\mathrm{O}_{3}$ can cause inflammation of airway and damage the lung function(Hwang et al., 2015). Nevertheless, it found that $\mathrm{O}_{3}$ had no deleterious effects on lung function in children in this study. The results of previous epidemiological studies about the impacts of $\mathrm{O}_{3}$ on the lung health were also inconsistent. A repeated-measure study conducted in Beijing found that no significant associations between the exposure of $\mathrm{O}_{3}$ and lung function of middle-school students were found. For example, per interquartile range (IQR) increase in concentrations of $\mathrm{O}_{3}$ was associated with -7.4\% (95\% CI: $-22.2 \%, 10.3 \%)$ and $-10.0 \%$ (95\% CI: $-22.0 \%, 3.8 \%)$ reduction in FEV1 and peak expiratory flow (PEF), respectively(Huang et al., 2019). However, for every 1 IQR increase in the past two months average concentrations of $\mathrm{O}_{3}$ in Taiwan, FVC and FEV1 of students decreased by $142 \mathrm{ml}$ and 131 ml, respectively (Chen et al., 2015$)$. Because the time unit was one quarter in this study, and the exposure levels of one quarter, two quarters and three quarters before the day of testing lung function were assessed. The season of testing was winter, so the exposure levels of $\mathrm{O}_{3}$ in spring, summer and Autumn were included. According to the previous studies, the concentrations of $\mathrm{O}_{3}$ in the air were higher in summer and lower in spring and autumn, so no significant harmful effects of $\mathrm{O}_{3}$ on lung function in children were found in this study(Chen et al., 2021).

More and more studies have shown that the existence of vegetation around the home may have a beneficial impact on people's physical and mental health (Twohig-Bennett \& Jones, 2018). Potential mechanisms include injury reduction (e.g., reduction of exposure to harmful pollutants, such as air pollution) and reviving capabilities (e.g., recovery of attention and stress) (Markevych et al., 2017). Studies have shown that residential greenness facilitated the development of children's lung function. A birth cohort study in the UK showed that, for every 1 IQR increase in greenness in a 100m buffer around the home address, FVC and FEV1 of students increased by 11.4 (95\% CI: $2.6,20.3)$ ml and $12.2(95 \%$ CI:1.8, 22.7) ml, respectively(Fuertes et al., 2020). However, a cross-sectional study found that no statistically significant associations between greenness around school and the lung function of students (Paciência et al., 2019). And in this study, protective effects of exposure levels of greenness on lung health at lag2 period (OR $=0.01$ (95\% CI: 0 - 0.02)) were stronger than those at lag1 period (OR $=0.03(95 \%$ CI: $0.01-0.05)$ ), this is because greening levels in summer were higher than those in autumn, and the lag2 period contained the summer and autumn, but the lag1 time period contained the only autumn. This means that exposure levels of greenness around home address had a positive association with lung function of children in this study. Meanwhile, researches about the relationship between greenness and the lung health of children were rare and the conclusions were inconsistent, we should investigate this in future studies.

In this study, the distance band of more than $400 \mathrm{~m}$ was used as the reference control and only the distance band of 101-200 m could be detrimental to the lung function of children significantly $(\mathrm{OR}=4.67$ (95\% CI: $1.21-8.13)$ ). Similarly, a study conducted in England found that the distance band of fewer than $150 \mathrm{~m}$ was not significantly associated with an increased risk of having asthma in children(Pujades-Rodríguez et al., 2009). This may be because of the shorter distance between the home address and major road, occupants could pay attention to the effects of air pollutants came from traffic emissions and change their life habits, such as keep windows and doors closed or opened and use air purifier reasonably. Further researches were needed.

For health effects of indoor air pollution risk factors after PSM, only the factor of secondhand smoke exposure was significantly associated with the elevated risks of having 
reduced lung function in the unadjusted model (OR $=2.4(95 \%$ CI: $1.2-3.6))$ and adjusted model (OR $=2.98$ (95\% CI: 1.39 - 4.56)). It is known smoking is a major cause of reduced lung function and smoking could cause the impairment of lung function by DNA methylation, chromium deposition in the lung, endothelial dysfunction and pulmonary vascular remodeling (Fresquez et al., 2017; Rossi et al., 2019). A cross-sectional study of workers found that passive smoking at home in childhood was not conducive to pulmonary function development (OR = 2.71 (95\% CI: 1.16-6.32) (Kanai et al., 2020). Besides, a cohort study of adults showed that the impaired lung function could be presented in people with secondhand smoke exposure and the risk of having COPD was higher in exposed populations (Hagstad et al., 2014). This implicates that hazardous effects of passive smoking on lung function must not be overlooked for childhood and adults.

For subgroup analysis in this study, except for $\mathrm{O}_{3}$, the harmful effects of nearly all air pollutants were stronger in females than males. In terms of lung size, the width of the airways of girls was relatively larger than that of boys in childhood (Sly \& Flack, 2008). In addition, the difference in hormone and metabolism levels between sex can also lead to the difference in air pollution effects (Yang et al., 2019). Meanwhile, since the female could spend more time at home and have greater airway responsiveness, air pollution had a greater impact on the lung health of females (Doiron et al., 2019). For the grouping variable of BMI, dangerous effects of PM 2.5 were stronger in overweight students than those in the non-overweight. A cohort study conducted in Dutch found that, for every $10 \mu \mathrm{g} / \mathrm{m}^{3}$ increase in concentrations of PM 10 , the FVC of people whose BMI was less than $25 \mathrm{~kg} / \mathrm{m}^{2}$ was reduced by $68 \mathrm{ml}$ and the FVC of those whose BMI was more than $25 \mathrm{~kg} / \mathrm{m}^{2}$ was reduced by $194 \mathrm{ml}$. The combined effects of excessive fat and air pollutant exposure on systemic inflammation and oxidative stress were greater than the simple additive effects of these two factors, indicating that the response to inflammatory stimulation of airway is enhanced in overweight students (Zeka et al., 2006).

Strengths of this study were as follows: First, indoor and outdoor environmental risk factors were used to perform PSM for students to estimate effects of outdoor and indoor environmental risk factors on reduced lung function in children, and the confounding effects could be well controlled. Second, the potential risk factors such as air pollution, road proximity, greenspace and indoor air pollution were all included in this study and the factors were comprehensive, which made our results more convincing. Third, we estimated the effects of indoor and outdoor environmental risk factors on the lung function of students in different gender and BMI subgroups, so we could distinguish the sensitive population more accurately.

However, there are still some limitations in this study. First, air pollution exposure levels of each student were estimated by the LUR model, but individual movement was not taken into account. That might lead to a certain degree of exposure bias. Second, in this study, indoor air pollution factors exposure levels were only obtained by questionnaires rather than monitoring instruments, so the representativeness of results could be attenuated. Third, our sample size was relatively small, and only students of primary school were included in this study. Further study should contain all age groups.

\section{Conclusion}

In this study, for the outdoor air pollution factors, the separate and combined effects of most air pollutants at different lag periods represented the hazard effects to the lung function of students and the harmful effects of $\mathrm{PM}_{2.5}$ were stronger in females and overweight students. And the distance band of $101-200 \mathrm{~m}$ between the home address of each 

effects on lung health for students. For the indoor air pollution factors, only the factor of secondhand smoke exposure was significantly associated with the elevated risk of having reduced lung function.

\section{Decalrations}

\section{Ethics approval and consent to participate}

We have verified consent from subjects participating in the study was received prior to conducting the study and provided written assurance that the study has been reviewed and approved by an accredited committee. The study was approved by the Committee on the Ethics of Tianjin Centers for Disease Control and Prevention (permit number:

314 TJCDC0111).

\section{Consent for publication}

$316 \quad$ Not applicable

\section{Availability of data and materials}

318 The datasets used and/or analysed during the current study are available from the corresponding author on reasonable request.

\section{Competing interests}

320 The authors declare that they have no competing interests

\section{Funding}

322 This research did not receive any specific grant from funding agencies in the public, commercial, or not-for-profit sectors.

323 Authors' contributions

324 Jingwei Zhang: Conceptualization, Methodology, Software.

325 Yuming Wang: Data curation, Writing- Original draft preparation.

326 LihongFeng: Visualization, Investigation.

327 Changchun Hou: Supervision, Software.

328 Qing Gu: Validation, Writing- Reviewing and Editing.

\section{Acknowledgements}

330 We would also like to thank the language editing service provided by Xiaoyu Chen (Monash University, Australia.). 
Agier, L, Basagaña, X, Maitre, L, Granum, B, Bird, P K, Casas, M, Oftedal, B, Wright, J, Andrusaityte, S, de Castro, M, Cequier, E, Chatzi, L, Donaire-Gonzalez, D, Grazuleviciene, R, Haug, L S, Sakhi, A K, Leventakou, V, McEachan, R, Nieuwenhuijsen, M, Petraviciene, I, Robinson, O, Roumeliotaki, T, Sunyer, J, Tamayo-Uria, I, Thomsen, C, Urquiza, J, Valentin, A, Slama, R, Vrijheid, M, \& Siroux, V (2019) Early-life exposome and lung function in children in Europe: an analysis of data from the longitudinal, population-based HELIX cohort. Lancet Planet Health 3: e81-e92. https://doi.org/10.1016/s2542-5196(19)30010-5.

Barone-Adesi, F, Dent, J E, Dajnak, D, Beevers, S, Anderson, H R, Kelly, F J, Cook, D G, \& Whincup, P H (2015) Long-Term Exposure to Primary Traffic Pollutants and Lung Function in Children: Cross-Sectional Study and Meta-Analysis. PLoS ONE 10: e0142565-e0142565. https://doi.org/10.1371/journal.pone.0142565.

Chao, X, Yi, L, Lan, L L, Wei, H Y, \& Wei, D (2020) Long-term PM(2.5) exposure increases the risk of non-small cell lung cancer (NSCLC) progression by enhancing interleukin-17a (IL-17a)-regulated proliferation and metastasis. Aging 12: 11579-11602. https://doi.org/10.18632/aging.103319.

Chen, C H, Chan, C C, Chen, B Y, Cheng, T J, \& Leon Guo, Y (2015) Effects of particulate air pollution and ozone on lung function in non-asthmatic children. Environ Res 137: 40-48. https://doi.org/10.1016/j.envres.2014.11.021.

Chen, J, Shi, C, Li, Y, Ni, H, Zeng, J, Lu, R, \& Zhang, L (2021) Effects of short-term exposure to ambient airborne pollutants on COPD-related mortality among the elderly residents of Chengdu city in Southwest China. Environ Health Prev Med 26: 7. https://doi.org/10.1186/s12199-020-00925-X.

Collaborators, C A H, \& Renzaho, A J J P (2019) Diseases, Injuries, and Risk Factors in Child and Adolescent Health, 1990 to 2017 Findings From the Global Burden of Diseases, Injuries, and Risk Factors. JAMA Pediatr 173: e190337. https://doi.org/10.1001/jamapediatrics.2019.0337

Dai, X, Bui, D S, Perret, J L, Lowe, A J, Frith, P A, Bowatte, G, Thomas, P S, Giles, G G, Hamilton, G S, Tsimiklis, H, Hui, J, Burgess, J, Win, A K, Abramson, M J, Walters, E H, Dharmage, S C, \& Lodge, C J (2021) Exposure to household air pollution over 10 years is related to asthma and lung function decline. Eur Respir J 57. https://doi.org/10.1183/13993003.00602-2020.

Dauchet, L, Hulo, S, Cherot-Kornobis, N, Matran, R, Amouyel, P, Edmé, J L, \& Giovannelli, J (2018) Short-term exposure to air pollution: Associations with lung function and inflammatory markers in non-smoking, healthy adults. Environ Int 121: 610-619. https://doi.org/10.1016/j.envint.2018.09.036.

Deng, Y, Gao, Q, Yang, D, Hua, H, Wang, N, Ou, F, Liu, R, Wu, B, \& Liu, Y (2020) Association between biomass fuel use and risk of hypertension among Chinese older people: A cohort study. Environ Int 138: 105620. https://doi.org/10.1016/j.envint.2020.105620.

Doiron, D, de Hoogh, K, Probst-Hensch, N, Fortier, I, Cai, Y, De Matteis, S, \& Hansell, A L (2019) Air pollution, lung function and COPD: results from the population-based UK Biobank study. Eur Respir J 54. https://doi.org/10.1183/13993003.02140-2018.

Fresquez, M R, Gonzalez-Jimenez, N, Gray, N, Valentin-Blasini, L, Watson, C H, \& Pappas, R S (2017) Electrothermal Vaporization-QQQ-ICP-MS for Determination of Chromium in Mainstream Cigarette Smoke Particulate. J Anal Toxicol 41: 307-312. https://doi.org/10.1093/jat/bkx010.

Fuertes, E, Markevych, I, Thomas, R, Boyd, A, Granell, R, Mahmoud, O, Heinrich, J, Garcia-Aymerich, J, Roda, C, Henderson, J, \& Jarvis, D (2020) Residential greenspace 
and lung function up to 24 years of age: The ALSPAC birth cohort. Environ Int 140: 105749. https://doi.org/https://doi.org/10.1016/j.envint.2020.105749.

Gauderman, W J, Urman, R, Avol, E, Berhane, K, McConnell, R, Rappaport, E, Chang, R, Lurmann, F, \& Gilliland, F (2015) Association of improved air quality with lung development in children. N Engl J Med 372: 905-913. https://doi.org/10.1056/NEJMoa1414123.

Geyti, C, Christensen, K S, Dalsgaard, E-M, Bech, B H, Gunn, J, Maindal, H T, \& Sandbaek, A (2020) Factors associated with non-initiation of mental healthcare after detection of poor mental health at a scheduled health check: a cohort study. BMJ open 10: e037731-e037731. https://doi.org/10.1136/bmjopen-2020-037731.

Hagstad, S, Bjerg, A, Ekerljung, L, Backman, H, Lindberg, A, Rönmark, E, \& Lundbäck, B (2014) Passive smoking exposure is associated with increased risk of COPD in never smokers. Chest 145: 1298-1304. https://doi.org/10.1378/chest.13-1349.

Huang, J, Song, Y, Chu, M, Dong, W, Miller, M R, Loh, M, Xu, J, Yang, D, Chi, R, Yang, X, Wu, S, Guo, X, \& Deng, F (2019) Cardiorespiratory responses to low-level ozone exposure: The inDoor Ozone Study in children (DOSE). Environ Int 131: 105021. https://doi.org/10.1016/j.envint.2019.105021.

Hwang, B F, Chen, Y H, Lin, Y T, Wu, X T, \& Leo Lee, Y (2015) Relationship between exposure to fine particulates and ozone and reduced lung function in children. Environ Res 137: 382-390. https://doi.org/10.1016/j.envres.2015.01.009.

Kanai, M, Kanai, O, Fujita, K, Mio, T, \& Ito, M (2020) Decreased handgrip strength can predict lung function impairment in male workers: a cross sectional study. BMC Pulm Med 20: 97-97. https://doi.org/10.1186/s12890-020-1135-9.

Kirenga, B J, Nantanda, R, de Jong, C, Mugenyi, L, Meng, Q, Aniku, G, Williams, S, Aanyu-Tukamuhebwa, H, Kamya, M, Schwander, S, van der Molen, T, \& Mohsenin, V (2018) Lung Function of Children at Three Sites of Varying Ambient Air Pollution Levels in Uganda: A Cross Sectional Comparative Study. Int J Environ Res Public Health 15: 2653. https://doi.org/10.3390/ijerph15122653.

Laborde, A, Tomasina, F, Bianchi, F, Bruné, M, Buka, I, Comba, P, Corra, L, Cori, L, Duffert, C M, \& Harari, R J E H P (2015) Children's Health in Latin America: The Influence of Environmental Exposures. Health Perspect 123: 201-209. https://doi.org/10.1289/ehp.1408292

Lee, A G, Kaali, S, Quinn, A, Delimini, R, Burkart, K, Opoku-Mensah, J, Wylie, B J, Yawson, A K, Kinney, P L, Ae-Ngibise, K A, Chillrud, S, Jack, D, \& Asante, K P (2019) Prenatal Household Air Pollution Is Associated with Impaired Infant Lung Function with Sex-Specific Effects. Evidence from GRAPHS, a Cluster Randomized Cookstove Intervention Trial. Am J Respir Crit Care Med 199: 738-746. https://doi.org/10.1164/rccm.201804-0694OC.

Lee, J Y, Leem, J H, Kim, H C, Lamichhane, D K, Hwang, S S, Kim, J H, Park, M S, Jung, D Y, Ko, J K, Kwon, H J, \& Hong, S J (2018) Effects of traffic-related air pollution on susceptibility to infantile bronchiolitis and childhood asthma: A cohort study in Korea. J Asthma 55: 223-230. https://doi.org/10.1080/02770903.2017.1313270.

Liu, L, Zhou, Q, Yang, X, Li, G, Zhang, J, Zhou, X, \& Jiang, W (2020) Cytotoxicity of the soluble and insoluble fractions of atmospheric fine particulate matter. J Environ Sci (China) 91: 105-116. https://doi.org/10.1016/j.jes.2020.01.012.

Luo, K, Li, R, Wang, Z, Zhang, R, \& Xu, Q (2017) Effect modification of the association between temperature variability and daily cardiovascular mortality by air pollutants 
in three Chinese cities. Environ Pollut 230: 989-999. https://doi.org/10.1016/j.envpol.2017.07.045.

Markevych, I, Schoierer, J, Hartig, T, Chudnovsky, A, Hystad, P, Dzhambov, A M, de Vries, S, Triguero-Mas, M, Brauer, M, Nieuwenhuijsen, M J, Lupp, G, Richardson, E A, Astell-Burt, T, Dimitrova, D, Feng, X, Sadeh, M, Standl, M, Heinrich, J, \& Fuertes, E (2017) Exploring pathways linking greenspace to health: Theoretical and methodological guidance. Environ Res 158: 301-317. https://doi.org/10.1016/j.envres.2017.06.028.

Miller, M, Marty, M A, \& Landrigan, P J J P C o N A (2016) Children's Environmental Health: Beyond National Boundaries. Pediatr Clin N Am 63: 149-165. https://doi.org/10.1016/j.pcl.2015.08.008

Miller, M R, Hankinson, J, Brusasco, V, Burgos, F, Casaburi, R, Coates, A, Crapo, R, Enright, P, van der Grinten, C P, Gustafsson, P, Jensen, R, Johnson, D C, MacIntyre, N, McKay, R, Navajas, D, Pedersen, O F, Pellegrino, R, Viegi, G, \& Wanger, J (2005) Standardisation of spirometry. Eur Respir J 26: 319-338. https://doi.org/10.1183/09031936.05.00034805.

Mou, Y, Song, Y, Xu, Q, He, Q, \& Hu, A (2018) Influence of Urban-Growth Pattern on Air Quality in China: A Study of 338 Cities. Int J Environ Res Public Health 15: 1805. https://doi.org/10.3390/ijerph15091805.

Nordeide Kuiper, I, Svanes, C, Markevych, I, Accordini, S, Bertelsen, R J, Bråbäck, L, Heile Christensen, J, Forsberg, B, Halvorsen, T, Heinrich, J, Hertel, O, Hoek, G, Holm, M, de Hoogh, K, Janson, C, Malinovschi, A, Marcon, A, Miodini Nilsen, R, Sigsgaard, T, \& Johannessen, A (2021) Lifelong exposure to air pollution and greenness in relation to asthma, rhinitis and lung function in adulthood. Environ Int 146: 106219. https://doi.org/10.1016/j.envint.2020.106219.

Oerlemans, A M, Wardenaar, K J, Raven, D, Hartman, C A, \& Ormel, J (2020) The association of developmental trajectories of adolescent mental health with early-adult functioning. PLoS ONE 15: e0233648-e0233648. https://doi.org/10.1371/journal.pone.0233648.

Paciência, I, \& Moreira, A (2017) Human health: is it who you are or where you live? Lancet Planet Health 1: e263-e264. https://doi.org/10.1016/s2542-5196(17)30123-7.

Paciência, I, Rufo, J C, Silva, D, Martins, C, Mendes, F, Rama, T, Rodolfo, A, Madureira, J, Delgado, L, de Oliveira Fernandes, E, Padrão, P, Moreira, P, Severo, M, Pina, M

F, Teixeira, J P, Barros, H, Ruokolainen, L, Haahtela, T, \& Moreira, A (2019) School environment associates with lung function and autonomic nervous system activity in children: a cross-sectional study. Sci Rep 9: 15156. https://doi.org/10.1038/s41598-019-51659-y.

Pujades-Rodríguez, M, Lewis, S, McKeever, T, Britton, J, \& Venn, A (2009) Effect of living close to a main road on asthma, allergy, lung function and chronic obstructive pulmonary disease. Occup Environ Med 66: 679-684. https://doi.org/10.1136/oem.2008.043885.

Pulvers, K, Nollen, N L, Rice, M, Schmid, C H, Qu, K, Benowitz, N L, \& Ahluwalia, J S (2020) Effect of Pod e-Cigarettes vs Cigarettes on Carcinogen Exposure Among African American and Latinx Smokers: A Randomized Clinical Trial. JAMA Netw Open 3: e2026324. https://doi.org/10.1001/jamanetworkopen.2020.26324. Raju, S, Siddharthan, T, \& McCormack, M C (2020) Indoor Air Pollution and Respiratory Health. Clin Chest Med 41: 825-843. https://doi.org/10.1016/j.ccm.2020.08.014. Rossi, R C, Anonni, R, Ferreira, D S, da Silva, L F F, \& Mauad, T (2019) Structural alterations and markers of endothelial activation in pulmonary and bronchial arteries in 
fatal asthma. Allergy Asthma Clin Immunol 15: 50-50. https://doi.org/10.1186/s13223-019-0363-0.

Ruokolainen, L, von Hertzen, L, Fyhrquist, N, Laatikainen, T, Lehtomäki, J, Auvinen, P, Karvonen, A M, Hyvärinen, A, Tillmann, V, Niemelä, O, Knip, M, Haahtela, T, Pekkanen, J, \& Hanski, I (2015) Green areas around homes reduce atopic sensitization in children. Allergy 70: 195-202. https://doi.org/10.1111/all.12545.

Schultz, E S, Hallberg, J, Bellander, T, Bergström, A, Bottai, M, Chiesa, F, Gustafsson, P M, Gruzieva, O, Thunqvist, P, Pershagen, G, \& Melén, E (2016) Early-Life Exposure to Traffic-related Air Pollution and Lung Function in Adolescence. Am J Respir Crit Care Med 193: 171-177. https://doi.org/10.1164/rccm.201505-0928OC.

Sly, P D, \& Flack, F (2008) Susceptibility of children to environmental pollutants. Ann N Y Acad Sci 1140: 163-183. https://doi.org/10.1196/annals.1454.017.

Strassmann, A, de Hoogh, K, Röösli, M, Haile, S R, Turk, A, Bopp, M, \& Puhan, M A (2021) NO2 and PM2.5 Exposures and Lung Function in Swiss Adults: Estimated Effects of Short-Term Exposures and Long-Term Exposures with and without Adjustment for Short-Term Deviations. Environ Health Perspect 129: 17009. https://doi.org/10.1289/ehp7529.

Twohig-Bennett, C, \& Jones, A (2018) The health benefits of the great outdoors: A systematic review and meta-analysis of greenspace exposure and health outcomes. Environ Res 166: 628-637. https://doi.org/https://doi.org/10.1016/j.envres.2018.06.030.

Urman, R, McConnell, R, Islam, T, Avol, E L, Lurmann, F W, Vora, H, Linn, W S, Rappaport, E B, Gilliland, F D, \& Gauderman, W J (2014) Associations of children's lung function with ambient air pollution: joint effects of regional and near-roadway pollutants. Thorax 69: 540-547. https://doi.org/10.1136/thoraxjnl-2012-203159.

Wu, Q Z, Li, S, Yang, B Y, Bloom, M, Shi, Z, Knibbs, L, Dharmage, S, Leskinen, A, Jalaludin, B, Jalava, P, Roponen, M, Lin, S, Chen, G, Guo, Y, Xu, S L, Yu, H Y, Zeeshan, M, Hu, L W, Yu, Y, Zeng, X W, \& Dong, G H (2020) Ambient Airborne Particulates of Diameter $\leq 1 \mu$ m, a Leading Contributor to the Association Between Ambient Airborne Particulates of Diameter $\leq 2.5 \mu \mathrm{m}$ and Children's Blood Pressure. Hypertension 75: 347-355. https://doi.org/10.1161/hypertensionaha.119.13504.

Xu, D, Zhang, Y, Zhou, L, \& Li, T (2018) Acute effects of PM(2.5) on lung function parameters in schoolchildren in Nanjing, China: a panel study. Environ Sci Pollut Res Int 25: 14989-14995. https://doi.org/10.1007/s11356-018-1693-Z.

Yang, H B, Teng, C G, Hu, J, Zhu, X Y, Wang, Y, Wu, J Z, Xiao, Q, Yang, W, Shen, H, \& Liu, F (2019) Short-term effects of ambient particulate matter on blood pressure among children and adolescents:A cross-sectional study in a city of Yangtze River delta, China. Chemosphere 237: 124510. https://doi.org/10.1016/j.chemosphere.2019.124510.

Yu, F, Ye, K, Hu, Y, Li, J, An, Y, \& Qu, D (2019) Exposure to polycyclic aromatic hydrocarbons derived from vehicle exhaust gas induces premature senescence in mouse lung fibroblast cells. Mol Med Rep 19: 4326-4334. https://doi.org/10.3892/mmr.2019.10086.

Yu, G, Gail, M H, Consonni, D, Carugno, M, Humphrys, M, Pesatori, A C, Caporaso, N E, Goedert, J J, Ravel, J, \& Landi, M T (2016) Characterizing human lung tissue microbiota and its relationship to epidemiological and clinical features. Genome biol 17: 163-163. https://doi.org/10.1186/s13059-016-1021-1.

Yuchi, W, Sbihi, H, Davies, H, Tamburic, L, \& Brauer, M (2020) Road proximity, air pollution, noise, green space and neurologic disease incidence: a population-based cohort 
study. Environ Health 19: 8. https://doi.org/10.1186/s12940-020-0565-4.

Zeka, A, Sullivan, J R, Vokonas, P S, Sparrow, D, \& Schwartz, J (2006) Inflammatory markers and particulate air pollution: characterizing the pathway to disease. Int J Epidemiol 35: 1347-1354. https://doi.org/10.1093/ije/dyl132.

Zhang, C, Guo, Y, Xiao, X, Bloom, M S, Qian, Z, Rolling, C A, Xian, H, Lin, S, Li, S, Chen, G, Jalava, P, Roponen, M, Hirvonen, M R, Komppula, M, Leskinen, A, Yim, S H L, Chen, D H, Ma, H, Zeng, X W, Hu, L W, Liu, K K, Yang, B Y, \& Dong, G H (2019) Association of Breastfeeding and Air Pollution Exposure With Lung Function in Chinese Children. JAMA Netw Open 2: e194186. https://doi.org/10.1001/jamanetworkopen.2019.4186.

Zhang, J, Feng, L, Hou, C, \& Gu, Q (2020) How the constituents of fine particulate matter and ozone affect the lung function of children in Tianjin, China. Environ Geochem Health 42: 3303-3316. https://doi.org/10.1007/s10653-020-00574-7.

Zhu, L, Ge, X, Chen, Y, Zeng, X, Pan, W, Zhang, X, Ben, S, Yuan, Q, Xin, J, Shao, W, Ge, Y, Wu, D, Han, Z, Zhang, Z, Chu, H, \& Wang, M (2017) Short-term effects of ambient air pollution and childhood lower respiratory diseases. Sci Rep 7: 4414. https://doi.org/10.1038/s41598-017-04310-7.

Table1 Descriptive statistics showing covariates and exposures in this case-control study in Tianjin, 2015-2018.

\begin{tabular}{|c|c|c|c|c|c|c|c|}
\hline \multirow[t]{2}{*}{ Level } & \multirow[t]{2}{*}{ Covariates } & \multicolumn{2}{|c|}{ Reduced lung function (before PSM ${ }^{\mathrm{a}}$ ) } & \multicolumn{4}{|c|}{$\begin{array}{l}\text { Reduced lung function (After PSM based on the } \\
\text { indoor factors) }\end{array}$} \\
\hline & & Non-case $(\mathrm{n}=106)$ & Case $(n=1981)$ & $\underset{\mathrm{b}}{P \text {-value }}$ & Non-case $(n=106)$ & Case $(n=106)$ & $P$-value \\
\hline \multicolumn{8}{|c|}{ Individual } \\
\hline & $\begin{array}{c}\text { SEX (Male/Female } \\
(\%))\end{array}$ & $1006 / 975(50.8 / 49.2)$ & $51 / 55(48.1 / 51.9)$ & 0.663 & $54 / 52(50.9 / 49.1)$ & $51 / 55(48.1 / 51.9)$ & 0.784 \\
\hline & $\mathrm{BMI}^{\mathrm{a}}\left(\right.$ mean $\left.\left(\mathrm{SD}^{\mathrm{a}}\right)\right)$ & $18.61(3.86)$ & $19.13(4.50)$ & 0.186 & $18.98(4.32)$ & $19.13(4.50)$ & 0.812 \\
\hline
\end{tabular}




\begin{tabular}{|c|c|c|c|c|c|c|c|}
\hline \multicolumn{7}{|c|}{ Father education $(\%)$} & \multirow[t]{2}{*}{0.038} \\
\hline & Primary school below & $0(0.0)$ & $1(0.9)$ & & $0(0.0)$ & $1(0.9)$ & \\
\hline & Primary school & $10(0.5)$ & $0(0.0)$ & & $0(0.0)$ & $0(0.0)$ & \\
\hline & Junior school & $46(2.3)$ & $2(1.9)$ & & $3(2.8)$ & $2(1.9)$ & \\
\hline & High school & $507(25.6)$ & $14(13.2)$ & & $31(29.2)$ & $14(13.2)$ & \\
\hline & College & $431(21.8)$ & $22(20.8)$ & & $25(23.6)$ & $22(20.8)$ & \\
\hline & Undergraduate & $440(22.2)$ & $33(31.1)$ & & $20(18.9)$ & $33(31.1)$ & \\
\hline \multirow{17}{*}{$\begin{array}{l}\text { Outdoor } \\
\text { factors }\end{array}$} & Postgraduate or above & 547 (27.6) & $34(32.1)$ & & $27(25.5)$ & $34(32.1)$ & \\
\hline & Mather education (\%) & & & 0.001 & & & 0.002 \\
\hline & Primary school below & $1(0.1)$ & $0(0.0)$ & & $1(0.9)$ & $0(0.0)$ & \\
\hline & Primary school & $8(0.4)$ & $2(1.9)$ & & $0(0.0)$ & $2(1.9)$ & \\
\hline & Junior school & $64(3.2)$ & $3(2.8)$ & & $5(4.7)$ & $3(2.8)$ & \\
\hline & High school & $517(26.1)$ & $9(8.5)$ & & $32(30.2)$ & $9(8.5)$ & \\
\hline & College & $444(22.4)$ & $24(22.6)$ & & $21(19.8)$ & $24(22.6)$ & \\
\hline & Undergraduate & $399(20.1)$ & $30(28.3)$ & & $22(20.8)$ & $30(28.3)$ & \\
\hline & Postgraduate or above & $548(27.7)$ & $38(35.8)$ & & $25(23.6)$ & $38(35.8)$ & \\
\hline & $\begin{array}{c}\text { NDVI lag1 (median } \\
\left.\left[\mathrm{IQR}^{\mathrm{a}}\right]\right)^{\mathrm{c}}\end{array}$ & $0.51[0.43,0.61]$ & $0.41[0.36,0.50]$ & $<0.001$ & $0.52[0.45,0.59]$ & $0.41[0.36,0.50]$ & $<0.001$ \\
\hline & $\begin{array}{c}\text { NDVI lag2 (median } \\
\text { [IQR]) }^{c}\end{array}$ & $0.55[0.48,0.62]$ & $0.45[0.40,0.52]$ & $<0.001$ & $0.55[0.49,0.61]$ & $0.45[0.40,0.52]$ & $<0.001$ \\
\hline & Road proximity (\%) & & & $<0.001$ & & & 0.003 \\
\hline & $0-50 \mathrm{~m}$ & $204(10.3)$ & $14(13.2)$ & & $11(10.4)$ & $14(13.2)$ & \\
\hline & $51-100 \mathrm{~m}$ & $471(23.8)$ & $24(22.6)$ & & $25(23.6)$ & $24(22.6)$ & \\
\hline & $101-200 \mathrm{~m}$ & $299(15.1)$ & $39(36.8)$ & & $17(16.0)$ & $39(36.8)$ & \\
\hline & $201-300 \mathrm{~m}$ & $210(10.6)$ & $10(9.4)$ & & $10(9.4)$ & $10(9.4)$ & \\
\hline & $301-400 \mathrm{~m}$ & $533(26.9)$ & $12(11.3)$ & & $28(26.4)$ & $12(11.3)$ & \\
\hline
\end{tabular}




\begin{tabular}{|c|c|c|c|c|c|c|}
\hline$>400 \mathrm{~m}$ & $263(13.3)$ & $7(6.6)$ & & $15(14.2)$ & $7(6.6)$ & \\
\hline $\begin{array}{l}\mathrm{PM}_{2.5} \mathrm{lag} 1(\text { median } \\
[\mathrm{IQR}])\left(\mu \mathrm{g} / \mathrm{m}^{3}\right)^{\mathrm{d}}\end{array}$ & $35.43[35.29,46.94]$ & $36.23[35.69,47.34]$ & 0.0037 & $35.94[35.69,46.53]$ & $36.23[35.69,47.34]$ & 0.007 \\
\hline $\begin{array}{c}\mathrm{PM}_{10} \text { lag1 (median } \\
[\mathrm{IQR}])\left(\mu \mathrm{g} / \mathrm{m}^{3}\right)\end{array}$ & $48.41[47.81,77.82]$ & $48.78[48.11,78.06]$ & 0.0016 & $48.29[48.11,78.01]$ & $48.78[48.11,78.06]$ & $<0.001$ \\
\hline $\begin{array}{l}\mathrm{NO}_{2} \operatorname{lag} 1(\text { median } \\
[\mathrm{IQR}])\left(\mu \mathrm{g} / \mathrm{m}^{3}\right)\end{array}$ & $32.86[26.35,34.18]$ & $28.38[27.19,32.70]$ & 0.142 & $31.79[27.23,34.02]$ & $28.38[27.19,32.70]$ & 0.354 \\
\hline $\begin{array}{l}\mathrm{SO}_{2} \operatorname{lag} 1(\text { median } \\
[\mathrm{IQR}])\left(\mu \mathrm{g} / \mathrm{m}^{3}\right)\end{array}$ & $6.07[5.25,8.48]$ & $6.40[6.08,9.48]$ & $<0.001$ & $6.08[5.57,9.10]$ & $6.40[6.08,9.48]$ & $<0.001$ \\
\hline $\begin{array}{l}\text { COlag1 (median } \\
[\mathrm{IQR}])\left(\mathrm{mg} / \mathrm{m}^{3}\right)\end{array}$ & $0.94[0.92,0.98]$ & $0.93[0.91,0.99]$ & 0.681 & $0.96[0.93,0.97]$ & $0.93[0.91,0.99]$ & 0.019 \\
\hline 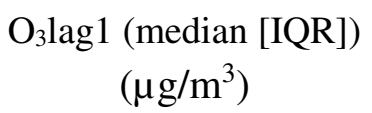 & $87.12[73.83,90.05]$ & $86.86[72.85,89.50]$ & 0.0813 & $86.19[76.06,89.50]$ & $86.86[72.85,89.50]$ & 0.186 \\
\hline $\begin{array}{l}\mathrm{PM}_{2.5} \mathrm{lag} 2(\text { median } \\
[\mathrm{IQR}])\left(\mu \mathrm{g} / \mathrm{m}^{3}\right)^{\mathrm{d}}\end{array}$ & $43.86[41.68,52.39]$ & $42.15[41.48,51.54]$ & $<0.001$ & $42.68[41.48,53.11]$ & $42.15[41.48,51.54]$ & 0.05 \\
\hline $\begin{array}{c}\text { PM } 10 \text { lag2 (median } \\
[\mathrm{IQR}])\left(\mu \mathrm{g} / \mathrm{m}^{3}\right)\end{array}$ & $66.95[67.46,80.07]$ & $69.36[67.97,81.28]$ & $<0.001$ & $67.97[67.97,80.37]$ & $69.36[67.97,81.28]$ & 0.001 \\
\hline $\begin{array}{l}\mathrm{NO}_{2} \operatorname{lag} 2(\text { median } \\
[\mathrm{IQR}])\left(\mu \mathrm{g} / \mathrm{m}^{3}\right)\end{array}$ & $33.61[30.83,38.74]$ & $31.58[30.46,35.41]$ & 0.064 & $34.56[30.46,39.20]$ & $31.58[30.46,35.41]$ & 0.022 \\
\hline $\begin{array}{l}\mathrm{SO}_{2} \mathrm{lag} 2(\text { median } \\
[\mathrm{IQR}])\left(\mu \mathrm{g} / \mathrm{m}^{3}\right)\end{array}$ & $6.13[6.41,11.27]$ & $7.53[6.82,11.65]$ & $<0.001$ & $6.82[6.63,11.45]$ & $7.53[6.82,11.65]$ & $<0.001$ \\
\hline $\begin{array}{l}\text { COlag2 (median } \\
[\mathrm{IQR}])\left(\mathrm{mg} / \mathrm{m}^{3}\right)\end{array}$ & $0.91[0.92,0.97]$ & $0.95[0.94,0.97]$ & 0.0191 & $0.94[0.94,0.96]$ & $0.95[0.94,0.97]$ & 0.111 \\
\hline $\begin{array}{c}\text { O}_{3} \text { lag2 } \\
(\text { median }[\mathrm{IQR}]) \\
\left(\mu \mathrm{g} / \mathrm{m}^{3}\right)\end{array}$ & $95.89[85.12,97.13]$ & $95.30[80.26,96.65]$ & 0.1633 & $94.92[84.13,96.65]$ & $95.30[80.26,96.65]$ & 0.073 \\
\hline
\end{tabular}




\begin{tabular}{|c|c|c|c|c|c|c|c|}
\hline & $\begin{array}{l}\mathrm{PM}_{2.5} \mathrm{lag} 3 \text { (median } \\
[\mathrm{IQR}])\left(\mu \mathrm{g} / \mathrm{m}^{3}\right)^{\mathrm{d}}\end{array}$ & $48.13[48.86,59.11]$ & $49.26[49.12,61.73]$ & $<0.001$ & $49.19[49.12,59.57]$ & $49.26[49.12,61.73]$ & 0.113 \\
\hline & $\begin{array}{l}\mathrm{PM}_{10} \mathrm{lag} 3 \text { (median } \\
\text { [IQR]) }\left(\mu \mathrm{g} / \mathrm{m}^{3}\right)\end{array}$ & $73.70[73.45,102.87]$ & $75.30[73.45,103.61]$ & $<0.001$ & $73.67[73.45,102.54]$ & $75.30[73.45,103.61]$ & $<0.001$ \\
\hline & $\begin{array}{l}\mathrm{NO}_{2} \operatorname{lag} 3(\text { median } \\
[\mathrm{IQR}])\left(\mu \mathrm{g} / \mathrm{m}^{3}\right)\end{array}$ & $37.43[36.80,40.57]$ & $37.24[36.80,40.43]$ & 0.791 & $39.51[36.89,44.69]$ & $37.24[36.80,40.43]$ & 0.284 \\
\hline & $\begin{array}{l}\mathrm{SO}_{2} \text { lag3 }(\text { median } \\
[\mathrm{IQR}])\left(\mu \mathrm{g} / \mathrm{m}^{3}\right)\end{array}$ & $10.19[10.21,18.96]$ & $10.93[10.49,20.41]$ & $<0.001$ & $10.49[10.42,19.88]$ & $10.93[10.49,20.41]$ & $<0.001$ \\
\hline \multirow{6}{*}{$\begin{array}{l}\text { Indoor } \\
\text { factors }\end{array}$} & $\begin{array}{l}\text { COlag3 }(\text { median } \\
[\mathrm{IQR}])\left(\mathrm{mg} / \mathrm{m}^{3}\right)\end{array}$ & $1.06[1.05,1.16]$ & $1.07[1.05,1.22]$ & 0.0073 & $1.05[1.05,1.26]$ & $1.07[1.05,1.22]$ & $<0.001$ \\
\hline & $\begin{array}{c}\mathrm{O}_{3} \operatorname{lag} 3(\operatorname{median}[\mathrm{IQR}]) \\
\left(\mu \mathrm{g} / \mathrm{m}^{3}\right)\end{array}$ & $77.87[66.84,78.52]$ & $77.96[67.10,79.36]$ & 0.0324 & $77.90[67.42,79.36]$ & $77.96[67.10,79.36]$ & 0.037 \\
\hline & $\begin{array}{c}\text { Smoking a } \\
\text { (None/Ever) (\%) }\end{array}$ & $1551 / 430(78.3 / 21.7)$ & $74 / 32(69.8 / 30.2)$ & 0.04 & $71 / 35(67.0 / 33.0)$ & $74 / 32(69.8 / 30.2)$ & 0.768 \\
\hline & Warm $^{a}(\mathrm{No} / \mathrm{Yes})(\%)$ & $1721 / 260(86.9 / 13.1)$ & $99 / 7(93.4 / 6.6)$ & 0.05 & $101 / 5(95.3 / 4.7)$ & 99/7 (93.4/6.6) & 0.766 \\
\hline & Fuel $^{\mathrm{a}}(\mathrm{No} / \mathrm{Yes})(\%)$ & $1620 / 361(81.8 / 18.2)$ & $87 / 19(82.1 / 17.9)$ & 1 & $86 / 20(81.1 / 18.9)$ & $87 / 19(82.1 / 17.9)$ & 1 \\
\hline & $\begin{array}{c}\text { Air purifier }{ }^{\mathrm{a}}(\mathrm{No} / \mathrm{Yes}) \\
(\%)\end{array}$ & $1387 / 594(70.0 / 30.0)$ & $66 / 40(62.3 / 37.7)$ & 0.114 & $61 / 45(57.5 / 42.5)$ & $66 / 40(62.3 / 37.7)$ & 0.575 \\
\hline
\end{tabular}

a PSM: Propensity score matching; BMI: Body mass index; IQR: Interquartile range; Smoking: Secondhand smoke exposure; Warm: The method of heating; Fuel: Fuel used for cooking; Air purifier: Air purifiers utilization.

${ }^{\mathrm{b}}$ Independent t-tests were applied for continuous independent variables, and chi-squared tests were applied for categorical independent variables.

c lag1, lag2: The exposure levels of greenness at one quarter and two quarters before the day of testing lung function, respectively.

${ }^{\mathrm{d}} \operatorname{lag} 1, \operatorname{lag} 2$ and lag3: the exposure levels of air pollutants at the one quarter, two quarters and three quarters before the day of testing lung function, respectively. 
Table 2 Joint effects of mixture of air pollutants on the reduced lung function incidence in children

\begin{tabular}{|c|c|c|c|}
\hline $\begin{array}{c}\text { Mixture of air } \\
\text { pollutants }\end{array}$ & $\begin{array}{c}\text { Estimated } \\
\text { percent change } \\
(\%)\end{array}$ & lower $95 \mathrm{CI}^{\mathrm{b}}$ & upper $95 \mathrm{CI}$ \\
\hline $\operatorname{Lag} 1^{\text {a }}$ & 1.46 & 1.38 & 1.54 \\
\hline $\operatorname{Lag} 2^{a}$ & 1.1 & 1.02 & 1.18 \\
\hline $\operatorname{Lag} 3^{\text {a }}$ & 1.08 & 1 & 1.18 \\
\hline
\end{tabular}

$464{ }^{a} \operatorname{lag} 1, \operatorname{lag} 2$ and lag3: the exposure levels of the mixture of air pollutants at the one quarter, two quarters and three quarters before the day of testing lung function, 465 respectively.

$466 \quad{ }^{\mathrm{b}} \mathrm{CI}$ : confidence interval

Table 3 Effects of indoor air pollution factors on the reduced lung function in children

\begin{tabular}{ccccc}
\hline Indoor factors & OR $^{\mathrm{c}}(\%)$ & ${\text { lower } 95 \mathrm{CI}^{\mathrm{c}}}^{\mathrm{c}}$ & upper 95CI & pvalue \\
\hline Smoking $^{\mathrm{a}}$ & 2.4 & 1.2 & 3.6 & 0.01 \\
Warm $^{\mathrm{a}}$ & 0.96 & 0.5 & 1.41 & 0.46 \\
Fuel $^{\mathrm{a}}$ & 0.89 & 0.47 & 1.32 & 0.73 \\
Air purifier $^{\mathrm{a}}$ & 0.77 & 0.43 & 1.1 & 0.37 \\
Smoking.adj $^{\mathrm{b}}$ & 2.98 & 1.39 & 4.56 & 0.01 \\
\hline
\end{tabular}

${ }^{a}$ Smoking: Secondhand smoke exposure; Warm: The method of heating; Fuel: Fuel used for cooking; Air purifier: Air purifiers utilization.

${ }^{\mathrm{b}}$ Smoking.adj:, Effects of secondhand smoke exposure after adjusted by other indoor air pollution factors.

$472 \quad{ }^{c}$ OR: Odds ratios ; CI: confidence interval 
Figures

\section{Image not available with this version}

Figure 1

Effects of air pollutants at different lag periods on the reduced lung function incidence in children. 


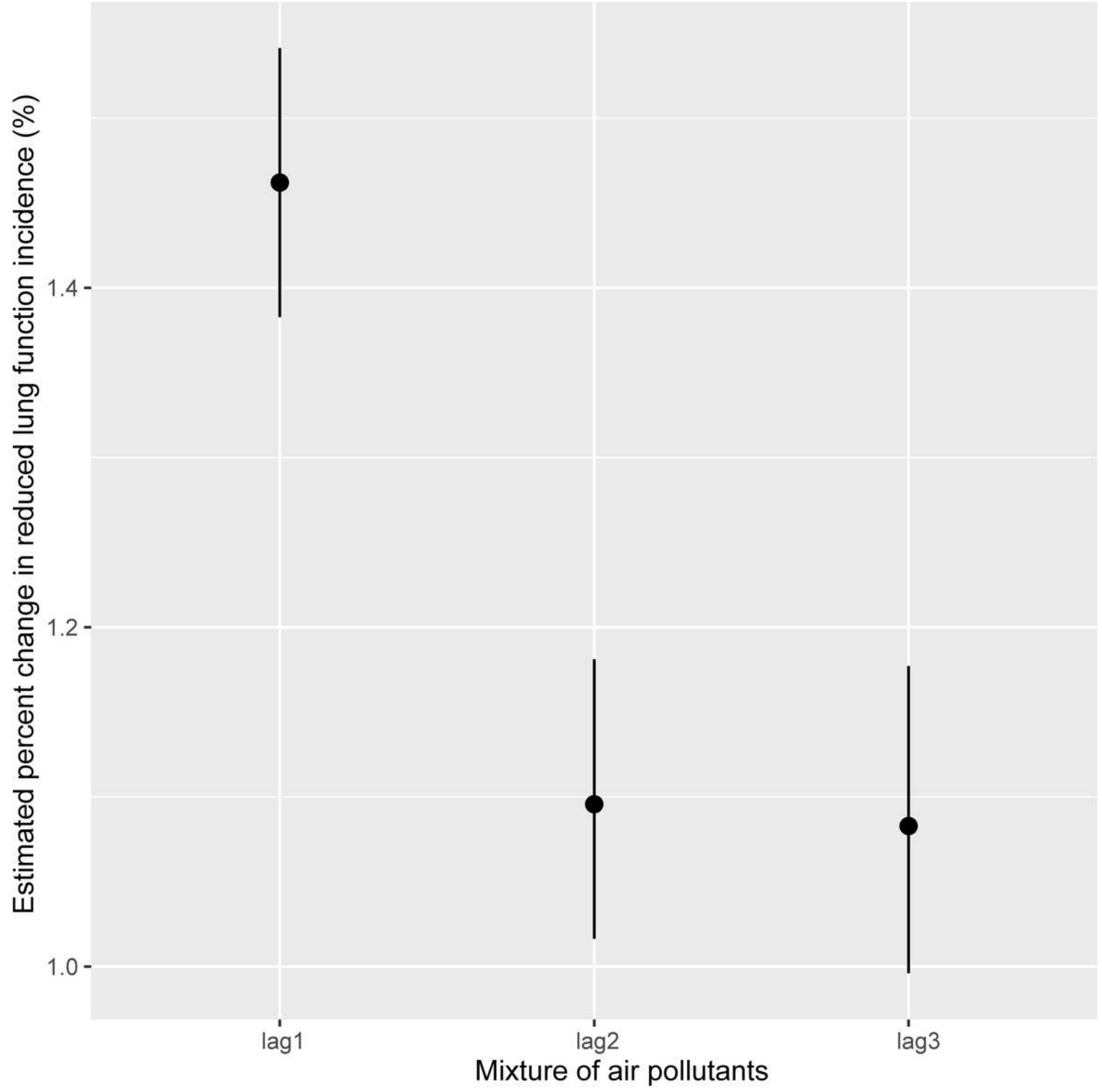

Figure 2

Joint effects of mixture of air pollutants on the reduced lung function incidence in children. 


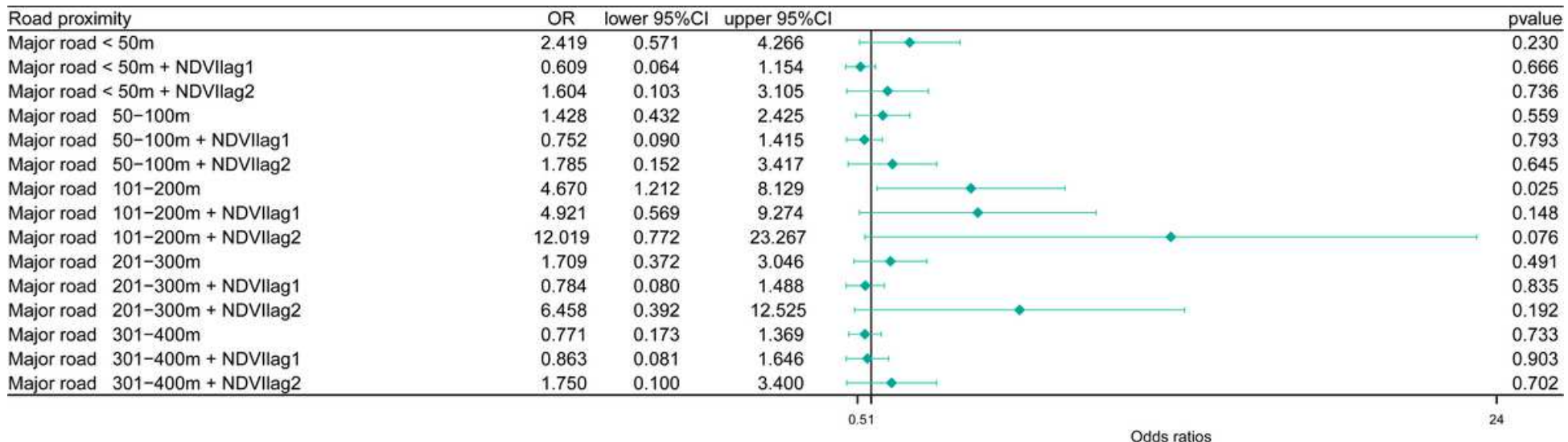

\section{Figure 3}

Effects of road proximity on the reduced lung function incidence in children.

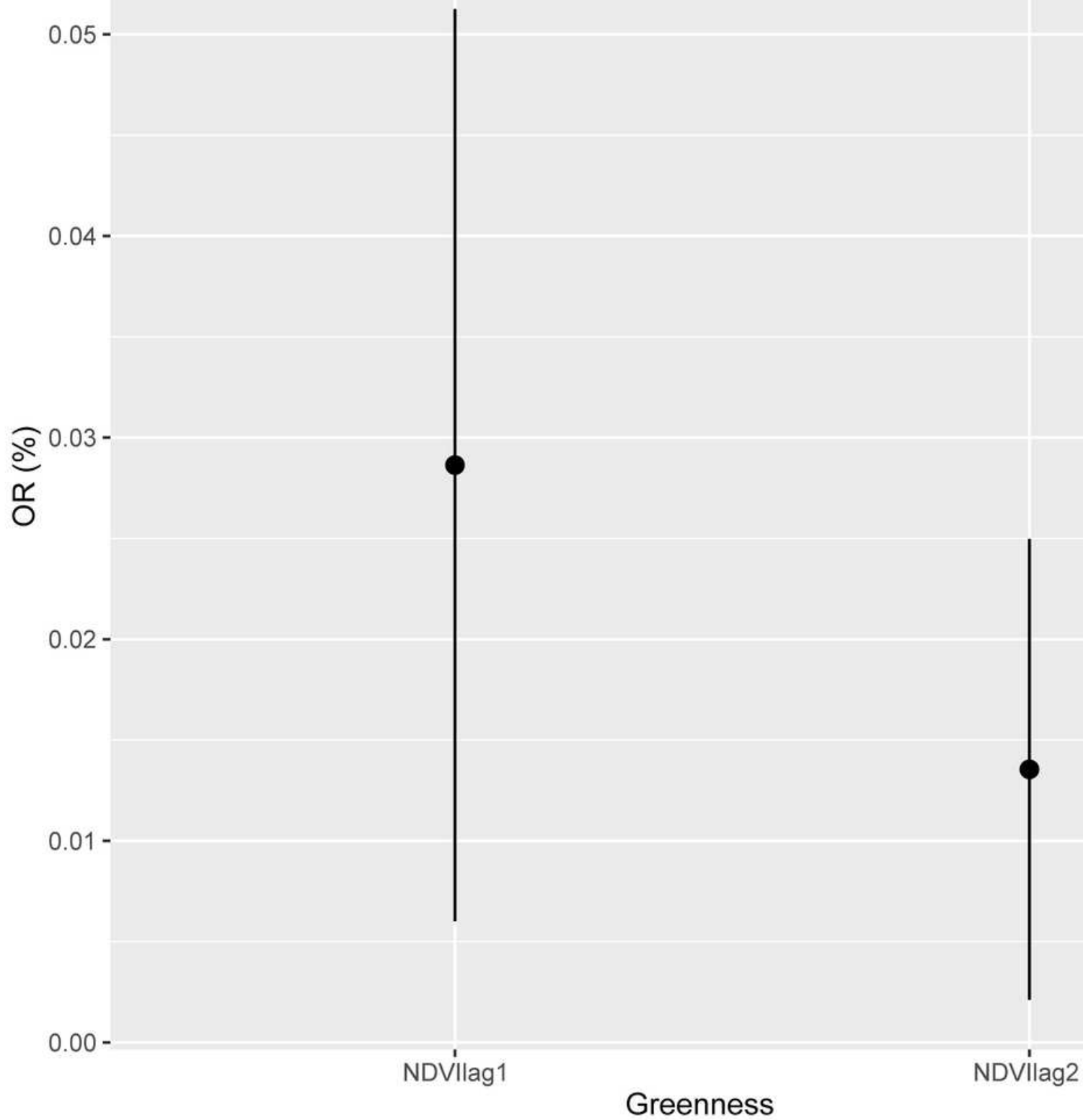


Figure 4

Effects of greenness exposure levels at different lag periods on the reduced lung function incidence in children.

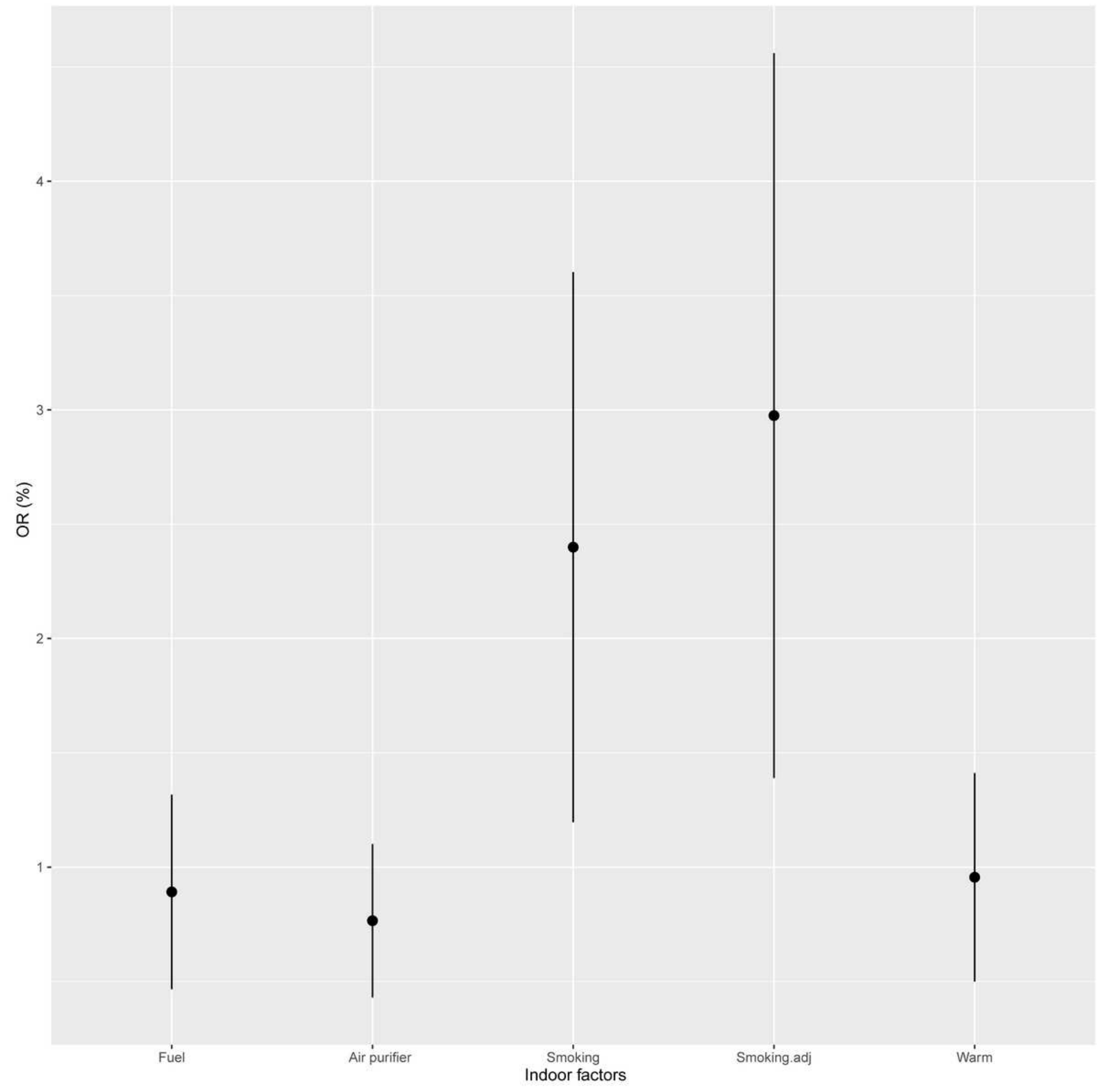

Figure 5

Effects of indoor air pollution factors on the reduced lung function incidence in children. 


\section{Supplementary Files}

This is a list of supplementary files associated with this preprint. Click to download.

- Fig.S1.tif

- Fig.S2.tif

- Fig.S3.tif

- Fig.S4.tif

- Fig.S5.tif

- Fig.S6.tif

- Fig.S7.tif

- Graphicalabstract.tif

- SupplementalMaterial.docx 